\title{
Pedobacter himalayensis sp. nov., from the Hamta glacier located in the Himalayan mountain ranges of India
}

\author{
S. Shivaji, P. Chaturvedi, G. S. N. Reddy and K. Suresh \\ Centre for Cellular and Molecular Biology, Uppal Road, Hyderabad 500 007, India
}

Correspondence
S. Shivaji
shivas@ccmb.res.in

\begin{abstract}
Strain HHS $22^{\top}$ was isolated from a glacial water sample from the snout of the Hamta glacier located in the Himalayan mountain ranges of India. Phenotypic, chemotaxonomic and phylogenetic analyses established the affiliation of the isolate to the genus Pedobacter. $\mathrm{HHS} 22^{\top}$ exhibits high 16S rRNA gene sequence similarity with Pedobacter cryoconitis (98\%). However, the level of DNA-DNA relatedness between HHS $22^{\top}$ and $P$. cryoconitis is only $42 \%$. Furthermore, HHS $22^{\top}$ differs from $P$. cryoconitis and the four other recognized species of Pedobacter in a number of phenotypic characteristics. These data suggest that HHS $22^{\top}$ represents a novel species of the genus Pedobacter, for which the name Pedobacter himalayensis sp. nov. is proposed. The type strain is HHS $22^{\top}\left(=\mathrm{JCM} 12171^{\top}=\right.$ MTCC $\left.6384^{\top}\right)$.
\end{abstract}

The genus Pedobacter was created to accommodate species characterized by Gram-negative rods that are heparinaseproducing, obligately aerobic, with or without gliding motility, negative for urease, lipase, gelatinase, arginine dihydrolase, indole production and nitrate reduction, and contain iso- $\mathrm{C}_{15: 0}$, iso- $\mathrm{C}_{15: 0} 2-\mathrm{OH}$, iso- $\mathrm{C}_{15: 0} 3-\mathrm{OH}, \mathrm{C}_{16: 0}$, $\mathrm{C}_{16: 1} \omega 5 c, \mathrm{C}_{16: 1} \omega 7 c, \mathrm{C}_{16: 0} 3-\mathrm{OH}$, iso- $\mathrm{C}_{17: 0} 3-\mathrm{OH}$ and iso$\mathrm{C}_{17: 1} \omega 9 c$ fatty acids (Steyn et al., 1998). Five species of Pedobacter have been described thus far, and they have been isolated from soil (Pedobacter heparinus, Pedobacter africanus and Pedobacter saltans), fish (Pedobacter piscium) and a glacier in the Tyrolean Alps (Austria) (Pedobacter cryoconitis) (Steyn et al., 1998; Margesin et al., 2003). In the present report, we have characterized a bacterium isolated from a glacial water sample collected from the snout of a glacier. Phenotypic, chemotaxonomic and phylogenetic analyses establish the affiliation of the isolate to the genus Pedobacter. The data also suggest that the isolate is different from the recognized species of Pedobacter. Therefore, it is proposed to assign the isolate to a novel species, for which the name Pedobacter himalayensis sp. nov. is proposed.

Three water samples were collected in sterile tubes from the Hamta glacier ( $4270 \mathrm{~m}$ above sea level) located in the Himalayan mountain ranges of India. When plated on nutrient agar plates $[0.5 \%(\mathrm{w} / \mathrm{v})$ peptone, $0.3 \%(\mathrm{w} / \mathrm{v})$ beef

Published online ahead of print on 3 December 2004 as DOI 10.1099/ ijs.0.63532-0.

The GenBank/EMBL/DDBJ accession number for the $16 \mathrm{~S}$ rRNA gene sequence of $\mathrm{HHS} 22^{\top}$ is AJ583425.

Phenotypic characteristics that differentiate strain $\mathrm{HHS} 22^{\top}$ and Pedobacter cryoconitis DSM $14825^{\top}$ are given in Supplementary Table A in IJSEM Online. extract, $0 \cdot 5 \%(\mathrm{w} / \mathrm{v}) \mathrm{NaCl}, 1 \cdot 5 \%(\mathrm{w} / \mathrm{v})$ agar, $\mathrm{pH} 7 \cdot 0$ ] and incubated at $22^{\circ} \mathrm{C}$ for 3 days, these samples yielded about $1 \cdot 8 \times 10^{4}$ to $4 \times 10^{5}$ c.f.u. $\mathrm{ml}^{-1}$. Based on their morphology these colonies could be grouped into 26 different morphotypes. Representative strains from each morphotype were initially characterized based on their 16S rRNA gene sequence. Analysis using the BLAST program indicated that all the strains were closely related to recognized species (>98\% sequence similarity). Strain HHS 1 is closely related to Pseudomonas meridiana (GenBank/EMBL/DDBJ accession no. AJ537602), HHS 5 and HHS 23 to Pseudomonas antarctica (AJ537601), HHS 12, HHS 13, HHS 24 and HHS 29 to Pseudomonas veronii (AY267192), HHS 3 and HHS 15 to Pseudomonas migulae (AY047218), HHS 2, HHS 9 and HHS 16 to Pseudomonas fluorescens (AY538263), HHS 8 to Pseudomonas lini (AY035996), HHS 17, HHS 18, HHS 19 and HHS 20 to Pseudomonas jessinii (AY391278), HHS 4 to Serratia marcescens (AF076038), HHS 6, HHS 7 and HHS 32 to Janthinobacterium lividum (AY247410), HHS 10 to Bacillus subtilis (AY672765), HHS 27 and HHS 28 to Hafnia alvei (AY572428), HHS 31 to Exiguobacterium acetylicum (AY297792) and HHS $22^{\mathrm{T}}$ to Pedobacter cryoconitis (AJ585231). Because these isolates were isolated from glacial water they are likely to be psychrophilic and may thus represent either a psychrophilic variant of the previously reported strain or a novel species. Strain HHS $22^{\mathrm{T}}$ was selected for detailed analysis to establish its identity based on a polyphasic taxonomic approach; a major consideration for choosing this strain was that only five species have been described so far for Pedobacter.

Strain HHS $22^{\mathrm{T}}$ was maintained on ABM $[0.5 \%(\mathrm{w} / \mathrm{v})$ peptone, $0 \cdot 2 \%(\mathrm{w} / \mathrm{v})$ yeast extract, $\mathrm{pH} 7 \cdot 0], \mathrm{LB}(1 \%$ 
tryptone, $0 \cdot 5 \%$ yeast extract, $1 \% \mathrm{NaCl}, \mathrm{pH} 7 \cdot 0$ ) or nutrient agar medium. It also grows on MacConkey's medium [1.7\% $(\mathrm{w} / \mathrm{v})$ peptone from casein, $0.3 \%(\mathrm{w} / \mathrm{v})$ peptone, $0.5 \%$ $(\mathrm{w} / \mathrm{v}) \mathrm{NaCl}, 1 \%(\mathrm{w} / \mathrm{v})$ lactose, $0.15 \%$ bile salt mixture, $0.03 \%(\mathrm{w} / \mathrm{v})$ neutral red, $0.001 \%(\mathrm{w} / \mathrm{v})$ crystal violet, $1.35 \%(w / v)$ agar], Ayers' agar [0.1\% (w/v) $\mathrm{NH}_{4} \mathrm{H}_{2} \mathrm{PO}_{4}$, $0.02 \%(\mathrm{w} / \mathrm{v}) \mathrm{KCl}, 0.02 \%(\mathrm{w} / \mathrm{v}) \mathrm{MgSO}_{4}, 0.015 \%$ bromothymol blue, $\mathrm{pH} 7 \cdot 0$ ] (Ayers et al., 1919), $\mathrm{R}_{2} \mathrm{~A}$ medium $[0.05 \%(\mathrm{w} / \mathrm{v})$ yeast extract, $0.05 \%(\mathrm{w} / \mathrm{v})$ peptone, $0.05 \%$ $(\mathrm{w} / \mathrm{v})$ Casamino acids, $0.05 \%(\mathrm{w} / \mathrm{v})$ glucose, $0.05 \%(\mathrm{w} / \mathrm{v})$ starch, $0.03 \%(\mathrm{w} / \mathrm{v})$ sodium pyruvate, $0.03 \%(\mathrm{w} / \mathrm{v})$ $\mathrm{K}_{2} \mathrm{HPO}_{4}, 0.005 \%(\mathrm{w} / \mathrm{v}) \quad \mathrm{MgSO}_{4}, \mathrm{pH}$ 7], TSA medium $[1 \cdot 7 \%(\mathrm{w} / \mathrm{v})$ casein enzyme hydrolysate, $0 \cdot 3 \%(\mathrm{w} / \mathrm{v})$ papaic digest of soyabean meal, $0.5 \%(\mathrm{w} / \mathrm{v}) \mathrm{NaCl}, 2.5 \%(\mathrm{w} / \mathrm{v})$ $\mathrm{K}_{2} \mathrm{HPO}_{4}, 2 \cdot 5 \%(\mathrm{w} / \mathrm{v})$ glucose, $\left.\mathrm{pH} 7 \cdot 3\right]$ and minimal medium $\left[1.05 \%(\mathrm{w} / \mathrm{v}) \mathrm{K}_{2} \mathrm{HPO}_{4}, 0.45 \%(\mathrm{w} / \mathrm{v}) \mathrm{KH}_{2} \mathrm{PO}_{4}\right.$, $0 \cdot 1 \%(\mathrm{w} / \mathrm{v})\left(\mathrm{NH}_{4}\right)_{2} \mathrm{SO}_{4}, 1.5 \%(\mathrm{w} / \mathrm{v})$ agar]. Phenotypic characteristics such as colony morphology, cell morphology, motility, various enzyme activities, carbon assimilation, acid and gas production, tolerance to temperature, $\mathrm{pH}$ and $\mathrm{NaCl}$, growth in various media and sensitivity to antibiotics at $22^{\circ} \mathrm{C}$ were ascertained as described by Reddy et al. (2000) using standard methods (Lanyi, 1987; Smibert \& Krieg, 1994). Heparinase activity was detected according to the method of Zimmermann et al. (1990). In addition, the ability of the culture to utilize a carbon compound as the sole carbon source was investigated by testing $0.5 \%$ carbon compound in minimal medium. Isolation of DNA and determination of the $\mathrm{G}+\mathrm{C}$ content of the DNA was determined as described by Shivaji et al. (1989a, b). Fatty acid methyl esters were prepared according to the method of Sato \& Murata (1988) and were analysed by gas chromatography as described by Shivaji et al. (2004, 2005).

To establish the phylogenetic position of strain HHS $22^{\mathrm{T}}$ further, its $16 \mathrm{~S}$ rRNA gene was sequenced. For this purpose, the genomic DNA was prepared, the 16S rRNA gene was amplified and sequenced as described by Shivaji et al. (2000), and sequences were aligned with those of recognized species of Pedobacter from the EMBL database using CLUSTAL V (Higgins et al., 1992). The PHYLIP package version 3.5c (Felsenstein, 1993) was implemented to compute pairwise evolutionary distances using DNADIST (Kimura, 1980), to resample the original sequence data 1000 times using SEQBOOT, to construct phylogenetic trees using FITCH, KITSCH and UPGMA, and for parsimony analysis using DNAPARS. In all cases, the input order of species added to the topology being constructed was randomized with the 'jumble' option with a random seed of seven and ten replications. Majority rule $(50 \%)$ consensus trees were constructed. Pedobacter cryoconitis DSM $14825^{\mathrm{T}}$ was used as a reference strain in studies related to morphology, biochemical tests, identification of fatty acids and DNADNA hybridization (which was carried out using the membrane filter method; Shivaji et al., 2004, 2005; Tourova \& Antonov, 1987).

Strain HHS $22^{\mathrm{T}}$ has morphological and biochemical characteristics similar to those reported for the genus Pedobacter (Steyn et al., 1998); i.e. cells are Gram-negative rods that are non-motile, it grows on heparin, is positive for oxidase, catalase, gelatinase, phosphatase and $\beta$ galactosidase, hydrolyses aesculin, assimilates lactose, glucose and mannose, is negative for $\mathrm{H}_{2} \mathrm{~S}$ production, indole production, urease, lipase and nitrate reduction, and does not produce acid from a large number of substrates (Table 1) (see species description for further details). In addition, the presence of iso- $\mathrm{C}_{15: 0}, \mathrm{C}_{16: 0}, \mathrm{C}_{16: 1} \omega 7 c$, iso$\mathrm{C}_{17: 1} \omega 9 c$ and iso- $\mathrm{C}_{17: 0} 3-\mathrm{OH}$ as the predominant fatty acids and a DNA G $+\mathrm{C}$ content of $41.25 \mathrm{~mol} \%$ (Table 1 and Table 2) further confirmed the similarity of strain HHS $22^{\mathrm{T}}$ with representative strains of members of the genus Pedobacter (Steyn et al., 1998). Furthermore, the almost-complete 16S rRNA gene sequence of HHS $22^{\mathrm{T}}$ (1455 nt) exhibits high similarity (>95\%) with four out of the five Pedobacter species with validly published names, namely Pedobacter cryoconitis (98\%), Pedobacter africanus (96\%), Pedobacter piscium (96\%) and Pedobacter heparinus (95\%). 16S rRNA gene sequence similarity with Pedobacter saltans is only $91 \%$. The phylogenetic tree constructed by using UPGMA and neighbour-joining shows that strain HHS $22^{\mathrm{T}}$ forms a coherent clade with those species showing greater than $95 \%$ sequence similarity and with a bootstrap resampling value of greater than $95 \%$, and is clearly separated from Pedobacter saltans (Fig. 1).

It is clear that strain HHS $22^{\mathrm{T}}$ represents a species of Pedobacter and that phylogenetically it is closely related to Pedobacter cryoconitis, which is a psychrophile. The level of DNA-DNA relatedness between HHS $22^{\mathrm{T}}$ and Pedobacter cryoconitis was only $42 \%$. In addition, HHS $22^{\mathrm{T}}$ differs from Pedobacter cryoconitis (see Supplementary Table A in IJSEM Online) and the other four Pedobacter species with validly published names (Table 1 and Table 2) in a number of phenotypic characteristics. Thus, we assign strain HHS $22^{\mathrm{T}}$ to a novel species, for which the name Pedobacter himalayensis sp. nov. is proposed. To our knowledge, this is the first species described from a Himalayan glacier.

\section{Description of Pedobacter himalayensis sp. nov.}

Pedobacter himalayensis (him.a.lay.en'sis. N.L. masc. adj. himalayensis pertaining to Himalaya).

Colonies on nutrient agar medium are round $(1 \cdot 6-2 \mathrm{~mm}$ in diameter), convex with complete margins, mucoid and pale white. Cells are aerobic, psychrotolerant, Gramnegative and non-motile. Grows between 4 and $25^{\circ} \mathrm{C}$ and $\mathrm{pH}$ 6-10. Optimum temperature and $\mathrm{pH}$ for growth are $22{ }^{\circ} \mathrm{C}$ and $\mathrm{pH} 7$, respectively. Growth occurs in the presence of $5 \cdot 8 \% \mathrm{NaCl}$. Grows on MacConkey's medium, Ayers' agar, $\mathrm{R}_{2} \mathrm{~A}$ medium, TSA medium, LB and minimal medium. Positive for catalase, oxidase, phosphatase, gelatinase, arginine decarboxylase, arginine dihydrolase, $\beta$-glucosidase, $\beta$-galactosidase, heparinase, tryptophan deamination and aesculin hydrolysis; negative for urease, lipase, lysine decarboxylase, ornithine decarboxylase, $\mathrm{H}_{2} \mathrm{~S}$ production, 


\section{Table 1. Phenotypic characteristics that differentiate Pedobacter himalayensis sp. nov. from related Pedobacter species}

All strains are positive for the following: aerobic growth, catalase, oxidase, phosphatase, $\beta$-galactosidase, aesculin hydrolysis; utilization of mannose, glucose and $\mathrm{N}$-acetylglucosamine as the sole carbon source. All strains are negative for the following: Gram stain; indole production; urease; reduction of nitrate to nitrite; utilization of erythritol, L-sorbose, xylitol, melezitose, dulcitol, citric acid, lysine and inositol as the sole carbon source; acid production from D-rhamnose and adonitol. +, Positive; -, negative; \pm , variable; NA, data not available; $\mathrm{S}$, susceptible; R, resistant.

\begin{tabular}{|c|c|c|c|c|c|c|}
\hline Biochemical tests & P. himalayensis ${ }^{\star}$ & P. cryoconitis $^{*}$ & P. heparinus ${ }^{\star}$ & P. africanus ${ }^{\star}$ & P. piscium ${ }^{\star}$ & P. saltans $^{*}$ \\
\hline Colony size $(\mathrm{mm})$ & $1 \cdot 6-2$ & $1 \cdot 6-2$ & $1-4$ & $2-4$ & $2-4$ & $2-4$ \\
\hline Colony colour & Pale white & Creamish white & Translucent yellow & Translucent yellow & $\begin{array}{c}\text { Yellow or } \\
\text { creamish white }\end{array}$ & Light yellow \\
\hline $\begin{array}{l}\text { Maximum growth } \\
\text { temperature }\left({ }^{\circ} \mathrm{C}\right)\end{array}$ & 25 & 25 & 37 & 37 & $25-30$ & $25-30$ \\
\hline $\begin{array}{l}\text { Growth on } \\
\text { MacConkey's } \\
\text { medium }\end{array}$ & + & - & - & - & - & - \\
\hline $\mathrm{H}_{2} \mathrm{~S}$ production & - & - & - & - & NA & - \\
\hline Lysine decarboxylase & - & - & + & + & + & + \\
\hline Tryptophan deaminase & + & - & - & - & $\mathrm{NA}$ & - \\
\hline Heparinase & + & - & + & + & - & + \\
\hline Arginine dihydrolase & + & - & - & - & $\mathrm{NA}$ & - \\
\hline Lipase & - & - & - & + & \pm & + \\
\hline$\beta$-Glucosidase & + & + & - & \pm & + & + \\
\hline \multicolumn{7}{|l|}{ Acid production from: } \\
\hline D-Arabinose & - & - & \pm & \pm & \pm & \pm \\
\hline D-Glucose & - & - & + & + & + & \pm \\
\hline D-Mannose & + & - & - & - & $\mathrm{NA}$ & NA \\
\hline D-Arabinose & + & - & - & \pm & - & \pm \\
\hline D-Xylose & + & + & + & \pm & + & + \\
\hline Ribose & + & - & - & \pm & - & - \\
\hline D-Glucose & + & + & - & - & - & + \\
\hline D-Galactose & + & + & + & + & \pm & + \\
\hline D-Fructose & + & + & + & \pm & + & \pm \\
\hline Methyl $\alpha$-D-mannoside & + & - & + & + & - & - \\
\hline Methyl $\alpha$-D-glucoside & + & + & + & + & + & \pm \\
\hline L-Fucose & + & + & + & \pm & - & - \\
\hline L-Rhamnose & + & - & + & + & \pm & + \\
\hline L-Melibiose & + & + & + & + & + & \pm \\
\hline D-Cellobiose & + & + & + & + & + & - \\
\hline Sucrose & + & + & + & + & + & \pm \\
\hline Trehalose & + & + & + & + & + & \pm \\
\hline D-Raffinose & + & + & - & - & + & \pm \\
\hline D-Maltose & + & + & + & \pm & + & + \\
\hline
\end{tabular}


Table 1. cont.

\begin{tabular}{|c|c|c|c|c|c|c|}
\hline Biochemical tests & P. himalayensis ${ }^{\star}$ & P. cryoconitis $^{\star}$ & P. heparinus* & P. africanus ${ }^{\star}$ & P. piscium ${ }^{\star}$ & P. saltans ${ }^{\star}$ \\
\hline Starch & + & - & - & \pm & + & - \\
\hline Inulin & + & + & - & - & - & - \\
\hline Glycogen & - & + & - & - & - & - \\
\hline Arbutin & + & + & \pm & \pm & + & + \\
\hline Salicin & + & + & + & \pm & + & + \\
\hline Mannitol & + & - & + & - & - & - \\
\hline Glycerol & + & - & - & - & NA & NA \\
\hline Adonitol & + & - & + & - & - & + \\
\hline D-Sorbitol & + & - & + & - & - & - \\
\hline Sodium fumarate & + & - & - & - & - & - \\
\hline Sodium succinate & + & - & - & \pm & - & - \\
\hline Pyruvate & + & - & + & \pm & - & - \\
\hline L-Alanine & + & - & - & \pm & - & - \\
\hline L-Serine & + & - & \pm & + & \pm & - \\
\hline L-Threonine & + & - & \pm & + & \pm & - \\
\hline L-Arginine & + & - & - & \pm & - & - \\
\hline L-Glutamic acid & + & - & - & + & + & - \\
\hline L-Aspartic acid & + & + & - & \pm & - & - \\
\hline L-Tyrosine & + & - & - & + & - & - \\
\hline L-Proline & + & - & - & \pm & + & - \\
\hline L-Histidine & - & - & - & \pm & - & - \\
\hline L-Creatinine & + & + & - & \pm & - & - \\
\hline \multicolumn{7}{|c|}{ Antibiotics used ( $\mu$ g per disc): } \\
\hline Tobramycin (15) & S & $\mathrm{R}$ & $\mathrm{R}$ & NA & NA & NA \\
\hline Amikacin (30) & S & $\mathrm{R}$ & $\mathrm{R}$ & NA & NA & NA \\
\hline Penicillin (10) & $\mathrm{R}$ & $\mathrm{R}$ & S & \pm & NA & \pm \\
\hline Kanamycin (30) & $\mathrm{R}$ & $\mathrm{R}$ & $\mathrm{R}$ & $\mathrm{NA}$ & NA & NA \\
\hline Chloramphenicol (30) & $\mathrm{R}$ & $\mathrm{R}$ & S & \pm & NA & S \\
\hline Ampicillin (10) & $\mathrm{R}$ & $\mathrm{R}$ & $\mathrm{R}$ & $\mathrm{R}$ & NA & \pm \\
\hline Tetracycline (30) & $\mathrm{R}$ & $\mathrm{R}$ & S & $\mathrm{R}$ & $\mathrm{NA}$ & $\bar{S}$ \\
\hline Sulfamethoxyazole (50) & S & S & S & S & NA & S \\
\hline $\begin{array}{l}\mathrm{G}+\mathrm{C} \text { content of DNA } \\
(\mathrm{mol} \%)\end{array}$ & $41 \cdot 0$ & $43 \cdot 0$ & $42-43$ & $43-45$ & $40-43$ & $36-38$ \\
\hline
\end{tabular}

${ }^{*}$ Data for Pedobacter himalayensis HHS $22^{\mathrm{T}}$ and Pedobacter cryoconitis DSM $14825^{\mathrm{T}}$ are from the present study, whereas data for Pedobacter heparinus LMG $10339^{\mathrm{T}}$, Pedobacter africanus LMG $10353^{\mathrm{T}}$, Pedobacter piscium LMG $14024^{\mathrm{T}}$ and Pedobacter saltans $\mathrm{LMG} 10337^{\mathrm{T}}$ are from Steyn et al. (1998).

methyl red test, indole test, Voges-Proskauer test, hydrolysis of starch and reduction of nitrate to nitrite. Acid is produced from D-xylose, D-mannose, sorbitol, mannitol and inositol, but not from $\mathrm{D}$-arabinose, D-ribose, D-glucose, D-fructose, D-galactose, D-rhamnose, sucrose, D-lactose, Dmaltose, D-cellobiose, D-melibiose, trehalose, D-raffinose or adonitol. Utilizes D-arabinose, L-arabinose, L-xylose, Dxylose, D-ribose, D-glucose, D-galactose, D-fructose, Dmannose, $N$-acetylglucosamine, methyl $\alpha$-D-mannoside, methyl $\alpha$-D-glucoside, L-rhamnose, L-fucose, L-melibiose, D-cellobiose, sucrose, trehalose, lactose, D-maltose, Draffinose, cellulose, starch, inulin, arbutin, salicin, Dmannitol, glycerol, adonitol, D-sorbitol, citrate, malonate, lactic acid, hydroxybutyric acid, hydroxybenzoic acid, sodium gluconate, sodium fumarate, sodium acetate, sodium succinate, succinic acid, pyruvate, polyethylene glycol, sodium thioglycolate, L-alanine, L-valine, L-leucine, L-isoleucine, L-serine, L-threonine, L-arginine, L-glutamic acid, L-aspartic acid, L-glutamine, L-asparagine, L-methionine, L-cysteine, L-tyrosine, L-phenylalanine, L-tryptophan, L-proline and L-creatinine; but not L-sorbose, dextran, glycogen, dulcitol, erythritol, xylitol, inositol, L-malate, sodium formate, DL-malic acid, citric acid, L-glycine, Llysine or L-histidine as sole carbon source. Cells are sensitive to ( $\mu$ g per disc): norfloxacin (10), lomefloxacin (30), tobramycin (15), amikacin (30), vancomycin (30), cotrimoxazole (25), sulfamethoxazole (50), doxycyclin (100), clindamycin (50) and trimethoprim (50), but resistant to roxithromycin (30), ciprofloxacin (30), nitrofurantoin (300), penicillin (10), cefoperazone (75), cefuroxime (20), lincomycin (2), cephotaxime (30), colistin (10), cefazolin (30), kanamycin (30), novobiocin (30), chloramphenicol 
Table 2. Fatty acid composition (\%) of Pedobacter himalayensis sp. nov. and related Pedobacter species

Pedobacter himalayensis HHS $22^{\mathrm{T}}$ and Pedobacter cryoconitis DSM $14825^{\mathrm{T}}$ were grown in TSA medium at $22^{\circ} \mathrm{C}$ for the determination of fatty acid composition in the present study. Data for Pedobacter heparinus DSM $2366^{\mathrm{T}}$, Pedobacter africanus DSM $12126^{\mathrm{T}}$, Pedobacter piscium DSM $11725^{\mathrm{T}}$ and Pedobacter saltans DSM $12145^{\mathrm{T}}$ are from Steyn et al. (1998). Trace, $<1 \%$; - , not detected; ECL, equivalent chain length.

\begin{tabular}{|c|c|c|c|c|c|c|}
\hline Fatty acid & P. himalayensis & P. cryoconitis & P. heparinus & P. africanus & P. piscium & P. saltans \\
\hline $\mathrm{C}_{14: 0}$ & $1 \cdot 0$ & $1 \cdot 0$ & $1 \cdot 1$ & $1 \cdot 5$ & $1 \cdot 3$ & Trace \\
\hline $\mathrm{C}_{15: 1} \omega 6 c$ & - & - & - & Trace & - & $1 \cdot 4$ \\
\hline Iso- $\mathrm{C}_{15: 0}$ & $33 \cdot 0$ & $15 \cdot 0$ & $28 \cdot 2$ & $26 \cdot 6$ & $26 \cdot 2$ & $31 \cdot 4$ \\
\hline Iso- $\mathrm{C}_{15: 0} 3-\mathrm{OH}$ & $1 \cdot 5$ & $1 \cdot 9$ & $2 \cdot 5$ & $2 \cdot 1$ & $2 \cdot 5$ & $2 \cdot 8$ \\
\hline $\mathrm{C}_{16: 0}$ & $7 \cdot 3$ & $9 \cdot 1$ & $3 \cdot 0$ & $3 \cdot 8$ & $3 \cdot 3$ & $4 \cdot 0$ \\
\hline $\mathrm{C}_{16: 1} \omega 5 c$ & - & - & $1 \cdot 4$ & $2 \cdot 1$ & $3 \cdot 5$ & Trace \\
\hline $\mathrm{C}_{16: 1} \omega 7 c$ & $20 \cdot 0$ & $27 \cdot 0$ & $20 \cdot 2$ & $23 \cdot 7$ & $31 \cdot 4$ & $19 \cdot 6$ \\
\hline $\mathrm{C}_{16: 0} 3-\mathrm{OH}$ & - & - & $1 \cdot 5$ & $3 \cdot 1$ & $4 \cdot 5$ & Trace \\
\hline
\end{tabular}

(30), ampicillin (10), tetracycline (30), amoxicillin (100), erythromycin (15), streptomycin (10) and nalidixic acid (30). The $\mathrm{G}+\mathrm{C}$ content of the DNA is $41 \mathrm{~mol} \%$. The major menaquinones present are MK-7 (68\%), MK-7 $\left(\mathrm{H}_{2}\right)(5 \%)$, MK-8 (6\%), MK-8( $\left.\mathrm{H}_{2}\right)(13 \%)$ and MK-9 $\left(\mathrm{H}_{2}\right)(8 \%)$. The cellular fatty acids are $\mathrm{C}_{14: 0}(1 \%)$, iso- $\mathrm{C}_{15: 0}(33 \%)$, iso$\mathrm{C}_{15: 0} 2-\mathrm{OH}(2 \%)$, iso- $\mathrm{C}_{15: 0} 3-\mathrm{OH}(1 \cdot 5 \%), \mathrm{C}_{16: 0}(7 \cdot 3 \%)$, $\mathrm{C}_{16: 1} \omega 7 c(20 \%)$, iso- $\mathrm{C}_{17: 1} \omega 9 c(4 \%)$ and iso- $\mathrm{C}_{17: 0} 3-\mathrm{OH}$ $(6 \%)$.
The type strain, HHS $22^{\mathrm{T}}\left(=\mathrm{JCM} 12171^{\mathrm{T}}=\right.$ MTCC $6384^{\mathrm{T}}$ ), was isolated from a glacial water sample.

\section{Acknowledgements}

We would like to thank the Department of Biotechnology, Government of India, New Delhi, India, for funding. Our special thanks go to Sri Deepak Srivastava, Sri Siddhartha Swaroop and his team from the Glaciology Department of Geological Survey of India, Faridabad, India, for their help in the collection of the samples.

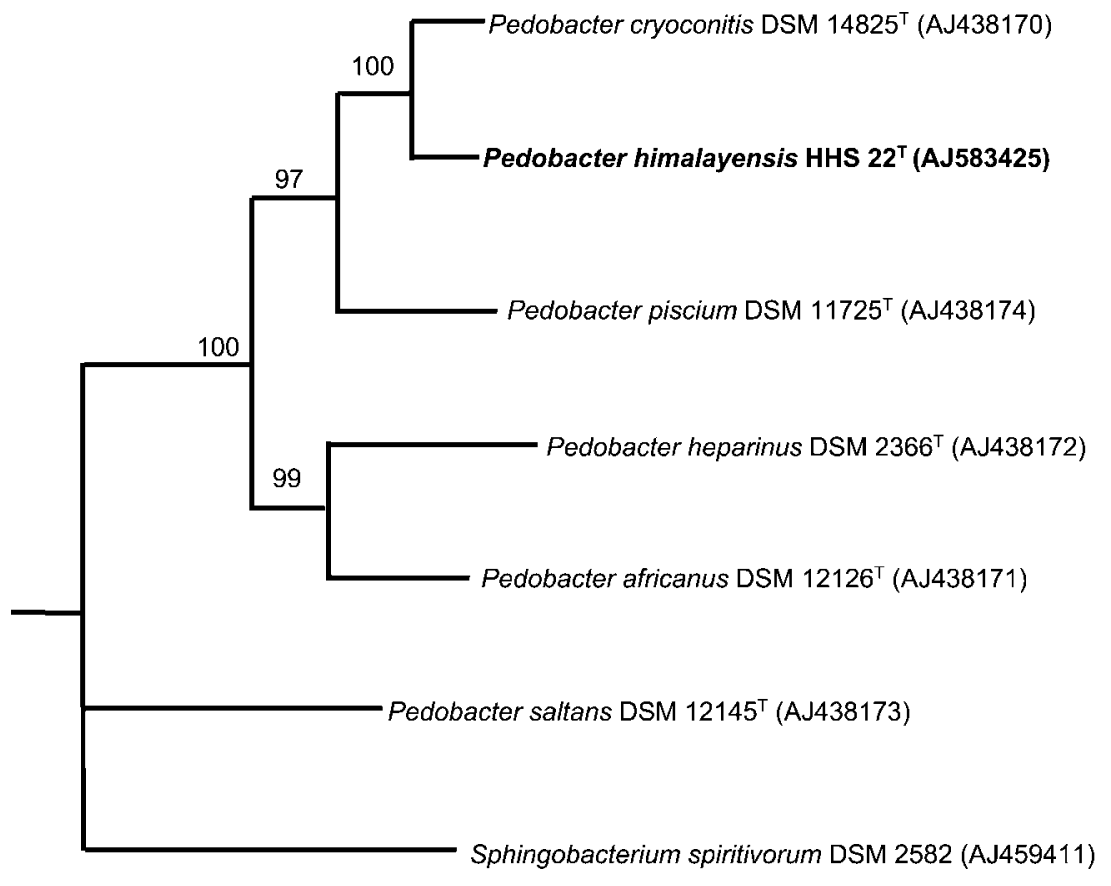

Fig. 1. Neighbour-joining tree based on 16S rRNA gene sequences (1455 bases) showing the phylogenetic relationship between Pedobacter himalayensis sp. nov. and species of the genus Pedobacter and Sphingobacterium spiritivorum. Bootstrap values (expressed as percentage of 1000 replications) greater than $50 \%$ are given at the nodes. 


\section{References}

Ayers, S. H., Rupp, P. \& Johnson, W. T. (1919). A study of the alkali forming bacteria in milk. US Dep Agric Bull 782.

Felsenstein, J. (1993). PHYLIP (phylogeny inference package), version 3.5c. Department of Genetics, University of Washington, Seattle, USA.

Higgins, D. G., Bleasby, A. T. \& Fuchs, R. (1992). Clustal V: improved software for multiple sequence alignment. Comput Appl Biosci 8, 189-191.

Kimura, M. (1980). A simple method for estimating evolutionary rates of base substitutions through comparative studies of nucleotide sequences. J Mol Evol 16, 111-120.

Lanyi, B. (1987). Classical and rapid identification methods for medically important bacteria. Methods Microbiol 19, 1-67.

Margesin, R., Spröer, C., Schumann, P. \& Schinner, F. (2003). Pedobacter cryoconitis sp. nov., a facultative psychrophile from alpine glacier cryoconite. Int J Syst Evol Microbiol 53, 1291-1296.

Reddy, G. S. N., Aggarwal, R. K., Matsumoto, G. I. \& Shivaji, S. (2000). Arthrobacter flavus sp. nov., a psychrotropic bacterium isolated from a pond in McMurdo Dry Valley, Antarctica. Int J Syst Evol Microbiol 50, 1553-1561.

Sato, N. S. \& Murata, N. (1988). Membrane lipids. Methods Enzymol 167, 251-259.

Shivaji, S., Rao, N. S., Saisree, L., Reddy, G. S. N., Kumar, G. S. \& Bhargava, P. M. (1989a). Isolates of Arthrobacter from the soils of Schirmacher Oasis, Antarctica. Polar Biol 10, 225-229.

Shivaji, S., Rao, N. S., Saisree, L., Sheth, V., Reddy, G. S. N. \& Bhargava, P. M. (1989b). Isolation and identification of
Pseudomonas spp. from Schirmacher Oasis, Antarctica. Appl Environ Microbiol 55, 767-770.

Shivaji, S., Bhanu, N. V. \& Aggarwal, R. K. (2000). Identification of Yersinia pestis as the causative organism of plague in India as determined by $16 \mathrm{~S}$ rDNA sequencing and RAPD based genomic fingerprinting. FEMS Microbiol Lett 189, 247-252.

Shivaji, S., Reddy, G. S. N., Raghavan, P. U. M., Sarita, N. B. \& Delille, D. (2004). Psychrobacter salsus sp. nov. and Psychrobacter adeliensis sp. nov. isolated from fast ice from Adelie Land, Antarctica. Syst Appl Microbiol 27, 628-635.

Shivaji, S., Reddy, G. S. N., Suresh, K., Gupta, P., Chintalapati, S., Schumann, P., Stackebrandt, E. \& Matsumoto, G. I. (2005). Psychrobacter vallis sp. nov. and Psychrobacter aquaticus sp. nov., from Antarctica. Int J Syst Evol Microbiol 55, 757-762.

Smibert, R. M. \& Krieg, N. R. (1994). Phenotypic characterization. In Methods for General and Molecular Bacteriology, pp. 607-654. Edited by P. Gerhardt. Washington, DC: American Society for Microbiology.

Steyn, P. L., Segers, P., Vancanneyt, M., Sandra, P., Kersters, K. \& Joubert, J. J. (1998). Classification of heparinolytic bacteria into a new genus, Pedobacter, comprising four species: Pedobacter heparinus comb. nov., Pedobacter piscium comb. nov., Pedobacter africanus sp. nov. and Pedobacter saltans sp. nov. Proposal of the family Sphingobacteriaceae fam. nov. Int J Syst Bacteriol 48, 165-177.

Tourova, T. P. \& Antonov, A. S. (1987). Identification of microorganisms by rapid DNA-DNA hybridisation. Methods Microbiol 19, 333-355.

Zimmermann, J. J., Langer, R. \& Cooney, C. L. (1990). Specific plate assay for bacterial heparinase. Appl Environ Microbiol 56, 3593-3594. 